\title{
Professionalising Peripheral Police Officers* in Kenya: Implications For Curriculum Development
}

\author{
Kenedy Onyango Asembo
}

\author{
Kasembo2005@yahoo.com \\ Mutendwahothe Walter Lumadi \\ Department of Curriculum and Instructional Studies \\ University of South Africa \\ lumadmw@unisa.ac.za
}

Doi:10.5901/mjss.2013.v4n13p781

\begin{abstract}
Management of non-professional Peripheral Police Officers (PPOs) has continued to pose a challenge to the Government of Kenya. The PPOs' arbitrary recruitment, lack of training, lack of standard operating procedures and vulnerability to political manipulation, among other factors, limit their ability to effectively discharge their duties as police officers. Consequently, the PPOs have been chiefly blamed for the proliferation of small arms and light weapons in the country, especially among the pastoralist communities, a phenomenon that has escalated the rate of crime in the country. In order to address the scourge, the government has put in place a training policy meant to professionalise the PPOs so they can effectively play a complementary role in delivering policing services to the citizenry. The objective of this study was to carry out a training needs analysis in order to develop a curriculum and training manual that would be used in implementing the training policy. The study adopted an Organisation-Task-Person model and found that, whereas the training needs point towards a traditional law enforcement curriculum, the stakeholders expect a postmodern force orientated towards community policing. Given the officers' semiliterate background, the dilemma is not so much delivering the much-desired traditional curriculum as reorienting the curriculum towards community policing. Using the Goldstein (1987) and Wong (2009) models of community policing, the study recommends a hybrid broad-based curriculum model, which combines both the traditional and postmodern aspects into a "partnership policing training model".
\end{abstract}

\section{Introduction}

Poor management of the Peripheral Police Officers ${ }^{1}$ (PPOs) in Kenya has been blamed for the increased availability of small arms and light weapons (SALWs) in the country. Even though Kenya's policy on SALWs has been to reduce all forms of proliferation by coordinating their management and control through legal, institutional and regulatory frameworks, the high rate of illicit trade in SALWs - especially in pastoralist areas, which are mainly policed by PPOs has overwhelmed security agencies. It is estimated that there are over 600000 illegal firearms in the country, a situation that has persistently fuelled both internal and cross-border insecurity (Wepundi, Nthiga, Kabuu, Murray \& Del Farte 2012; Mkuutu 2005).

The National Police Service Act of 2011 recognises the officers' key role in complementing the national police in rural areas, where police strength is inadequate. Nevertheless, over the years, efforts to professionalise the PPO as a security service have been lukewarm. Such challenges as arbitrary recruitment, poor firearm-handling skills, poor remuneration, lack of standard operating procedures and vulnerability to political manipulation have raised grave concerns about the administration of the security service (Wepundi 2011). Hence the majority of PPOs continue to operate as ragtag militia, especially in pastoralist areas. As the demand to disarm the population and ensure lasting peace for communities continues to increase, the role of the PPOs in this process remains crucial (Ndungu 2010). But their effectiveness in performing disarmament alongside their regular duties will rely significantly on their professionalism. Within the demand to recalibrate the PPO Service set out in the National Disarmament Action Plan, 2013, the Government of Kenya has prioritised training PPOs in professional policing skills (Kenya National Focal Point 2013). The

${ }^{1}$ For ethical reasons, Peripheral Police Officers (PPOs), Terare*, Swanga*, Wakondo*, Kabade*, Ligongo* Masukari*, Wayando Police Academy*, Ogongo Training School*; Chune Police Training College and Farasi Training Depot* are all pseudonyms. 
aim of this study was to carry out a training needs assessment (TNA) whose findings would guide the development of a curriculum and a training manual for PPOs. The objectives of the TNA were therefore to:

- Identify the needs of the stakeholders in security in relation to training PPOs.

- Determine the training needs of the PPOs in relation to performance of their duties.

- Examine the individual training needs of the PPOs.

- Explore how best the training needs can be addressed.

\section{Literature Review}

\subsection{Role of Peripheral Police Officers in policing}

The origin of PPOs as community police in Kenya dates back to 1948, when the British Colonial Administration established them as an unpaid volunteer force with its own hierarchy and rank structure (Mkuutu 2005). It has therefore existed as an ancillary force armed by the state to provide policing services in areas where police presence is not adequate. Such services have included collecting information and protecting livestock against stock theft, especially in pastoralist areas. To date, the force comprises mainly volunteers operating within their own localities (Mkuutu \& Wandera 2013).

A majority of Kenyans in the pastoralist areas view the PPOs as vital in providing the first response to security threats, due to their local knowledge and ability to operate in harsh climates and over difficult terrain. The PPOs in Terare County, for instance, continue to provide security for kraals and caravans and also fulfil the roles traditionally carried out by police. Their role as security personnel comprises $90 \%$ of police duties and is expected to increase as Wakondo town expands due to exploration for and discovery of oil. They have been recruited to guard schools, churches, private enterprises and NGOs, particularly those outside urban centres. Due to the low numbers of national police officers in the area, the business community in Terare is expected to continue needing their security services (Mkuutu \& Wandera 2013). In Kabade County, however, the PPOs work as scouts or rangers in conservancies. Whereas the traditional PPOs generally have only rudimentary support, those employed as scouts are provided with uniforms, some training and salaries, making it an attractive employment option.

Studies have indicated that despite their noble role, poor recruitment and training of the PPOs have compromised their professionalism and made them a source of concern (Mkuutu \& Wandera 2013). It is estimated that there are a total of 16500 PPOs in Kenya, with about 2000 in the Rift Valley and North Eastern Regions (Wepundi 2011; Mkuutu \& Wandera 2013). The majority have not had initial or refresher training and where training has been offered, there has been no attempt to provide standardised training for all. Consequently, in 2003 the government made attempts to disarm all 5000 PPOs countrywide, having lost confidence in their ability to professionally perform security duties (Wepundi 2011). Again in 2010, many PPOs were demobilised after reports of their involvement in criminal activities including banditry, trafficking in small arms and misuse of firearms. In particular, Bevan (2008) decries the selling and distribution of ammunition to locals by Terare County PPOs, including purchasing ammunition from neighbouring countries. Ndungu (2010) notes that some police PPOs have privatised the small arms given to them by the government and used them for criminal ends (Ndungu 2010). Similarly, Wepundi et al. (2012) highlight the hiring out of arms by PPOs to bandits or clan militia involved in raiding neighbouring communities, especially in Masukari County. In other instances arms given to PPOs are never returned to the government because they have been inherited or taken over by community members. Studies have blamed weak institutional controls, including lack of adequate training, as key reasons for the problem.

Nevertheless, pastoralist communities agree that the PPOs, as a quasi-governmental security service, are the best option for providing security in those regions (Wepundi et al. 2012; Wepundi 2011; Safer World and Amani Forum 2006). Wepundi (2011) notes that in Ligongo and Kabade counties, for instance, the locals have more confidence in the PPOs than in the national police. This approval rating, coupled with the recognition of the complementary role of PPOs in the National Police Act, 2011, creates a demand for a professionalised force equipped with the knowledge, skills and attitudes that will enable it to fully discharge its function (Safer World and Amani Forum 2006).

\subsection{Training needs of police officers}

Alpert and Dunham (1997) acknowledge the dynamic nature of police training and suggest the need for community police training to be guided by two main aspects: the skills, information and attitudes that one must develop to be a good police officer and the most efficient and effective methods to provide that training. To this end, researchers have documented 
the need to align police training with the day-to-day roles that officers perform, in order to bridge the gap between theory and practice (Bradford \& Pynes 1999; Marion 1998; Kochur 1997; McLaughlin \& Donahue 1995; Ness 1991; Meadows 1986; Scott 1981). Training should therefore not focus only on memorising laws, rules and procedures, but should be broadened to include police-public relations, customer care, interpersonal skills, problem-based learning, public speaking and organisational skills (Bradford \& Pyne 1999; Oliver 1998; Kelling, Wasserman \& Williams 1988), hence the need for police training to be community-oriented. Oettmeier and Wycoff (1994) contend that community policing requires police officers to work with the community in solving problems while exercising their discretionary powers. The focus is on policing that is less reactive but more proactive in meeting the needs of local communities. Goldstein (1990) emphasises that the measures of policing success, in this context, are a sense of a secure and crime-free atmosphere among the citizens; enhanced trust among the public; and strengthened police-public partnerships in solving security and policing challenges faced by the community.

Researchers have, however, faulted police training institutions for failing to deliver training that is relevant to an officer's daily workload and problem-solving challenges, especially in areas that require the officer to apply critical thinking and exercise discretion (Bradford \& Pynes 1999; Alpert \& Dunham 1997; Bayley \& Bittner 1984). Yet these options form the core of community policing. In her study of a police training curriculum regulated by the Ohio Peace Officer Training Academy, Marion (1998) established that recruits received only one hour of training in public relations, while such areas as ethics, information about the elderly population and victims of crime did not receive any formal training hours. Similarly, Brand and Peak (1995) surveyed Nevada Category 1 peace officers to determine the effectiveness of the state-mandated Police Officer Standards and Training academy training. The patrol officers recommended training in the areas of street language skills, verbal judo, courtroom testimony, field sobriety testing and gangs/cults/hate crimes. The findings suggested that the academy training did not adequately prepare officers for their day-to-day duties.

The increased demand for dynamic police officers who are able to use their skills to meet the day-to-day security needs of the community has made policing tasks broader in scope and less specific. This has transformed the police officer from a specialist to a jack of all trades: a resource and a problem-solver (Carnevale \& Carnevale 1993). Police authorities are expected to focus not just on technical skills but also on interpersonal and leadership skills. Metchik and Winton (1995) note that the demand goes beyond the technical approach to situations and puts greater emphasis on cognitive skills, creativity and flexibility to resolve problems more innovatively. Bullock (1995) contends that the contemporary police officer must be well-educated, flexible, creative, compassionate, proficient and tolerant.

In another study, Bradford and Pynes (1999), while arguing on the same principle, note that training a communityoriented police officer requires imparting those skills not previously taught in the traditional recruits' training. This necessitates training methods and a curriculum that assist police officers in facing their extended responsibilities of problem-solving. Such a curriculum needs to be orientated more towards cognitive than psychomotor skills and should include problem-solving, decision-making and interpersonal relations. Similarly, the recruitment and selection processes must be restructured to target knowledge, skills, abilities and other characteristics that are important for effective community-oriented policing. Given that the PPO in Kenya is recommended for recruitment by the community for the community, the need for training that would enable him or her to fulfil this role is crucial. The aim of this study was therefore to identify the individual and community training needs of the PPO in order to develop a curriculum that would train the officer to answer those needs.

\subsection{Training needs analysis}

The significance and value of training in improving an organisation's capacity to deliver its goals has been adequately documented. Therefore the need for a highly competent, skilled and trained police workforce in Kenya cannot be overstated. Ghufli (2012) explains that training is responsible for building skilled, qualified and capable people who help organisations to improve their performance and adapt to change. The training aims at effecting positive changes in the trainees in terms of their knowledge, skills and attitudes, thus improving their level of performance. Similarly, Flosi (2011) notes that training is a critical component of the success of any law enforcement agency.

The first important phase in planning and developing a training programme is to determine the needs for such a programme within an organisation (Boydell 1976). The idea behind TNA is that without a match between training needs and the content of training, beneficial outcomes of organisational performance cannot be realised (Van Eerde, Tang \& Talbot 2008). Anderson (2000) explains that the needs assessment is the starting point of the training process. It is the phase in which an organisation's needs are identified and forms the foundation of an effective training effort. The TNA 
indicates where and what kind of training programmes are needed, who needs to be included, conditions under which training will occur and criteria to guide training assessment. Therefore, TNA is an ongoing process of gathering data to determine what training needs exist so that training can be developed to help the organisation accomplish its objectives (Brown 2002). Since no TNA had been done on PPOs in Kenya, this study set out to fill this gap.

\section{Theoretical Framework}

\subsection{The Organisation-Task-Person model}

The TNA was based on the Organisation-Task-Person (OTP) model. This model was first presented by McGehee and Thayer (1961) and involves three analyses: organisational analysis, task analysis (or "operations analysis") and person analysis. Cheng and Hung (2012:17) explain that organisational analysis involves an examination of the entire organisation's priorities, abilities, resources and future personnel requirements in order to identify training needs. Similarly, task analysis identifies specific tasks for particular jobs and specifies the conditions, time, quality, quantity and frequency of performing the tasks. It also identifies the associated knowledge, skills and abilities needed to perform the tasks in an effective way and where and how they are to be acquired, in order to determine training programme content (Leat \& Lovell 1997; Goldstein 1991; Goldstein \& Gessner 1988). The person analysis is performed to determine individual training needs in order to assign the right training to the right person. Using information or data from employee performance reviews to determine training programme needs is the most common method. Additionally, employees can be surveyed, interviewed or tested to identify their training needs (Brown 2002; Scott \& Deadrick 1982).

The Performance Analysis model proposed by Mager and Pipe (1984) is an alternative TNA model that focuses on identifying the areas of discrepancy between desired and actual performance and subsequently analysing the causes of such discrepancies. However, this study adopted the OTP model, which is the core framework for TNA (Holton, Bates \& Naquin 2000), since it provides a comprehensive needs analysis and increases the likelihood of aligning training with organisational and individual needs (Cheng \& Hung 2012). It therefore helped to address the key questions of the study, focusing on the needs of the stakeholders in relation to training PPOs, the individual needs of PPOs and those needs related to performance of their duties.

\subsection{The Social Resource theory and Problem-Oriented Policing}

The concept of a professional PPO as a community police officer is based on Kam C Wong's Social Resource theory, which conceptualises the role of police from the perspective of the people, not that of the state. It views crimes as personal problems and police officers as resources made available to the people to use in solving their own problems (Wong 2009:91). This concept is indebted to the ideas of Sir Robert Peel (1788-1850), who stressed crime prevention, public approval, respect for and cooperation with the public, accountability, minimal use of physical force and impartiality as the hallmarks of ideal policing (Lentz \& Chaires 2007). Just as Peel concluded that the police are the people and the people are the police, Wong emphasises that from the people's perspective, police power is a social resource provided to the citizens by the state to be used in handling "personal problems of an emergency nature or crisis kind". In such circumstances, the power is not packaged in political likeness, legislative boundaries and police organisational culture but is directed by the people and repackaged to address the specific security situations prevailing at the time (Wong 2009:92).

Problem-Oriented Policing (POP) was first introduced by Goldstein (1987) when he criticised the tendency of police to be preoccupied with procedures at the expense of results. He therefore advocated reorienting police activities to POP. The POP concept redefined the role of the police from one of law enforcers and crime fighters to one of problemsolvers. Problem-solving involves examining the causes and the consequences of, and providing alternatives to, community problems (Wong 2009). The main difference between Goldstein and Wong is that whereas Goldstein wants the police to take a leading role in solving community problems, thereby increasing penetration of communities by state agents, Wong wants the community to take a commanding role, increase more civic society space and solve their problems with or without the help of the police - the police being just one of many available resources. The role of police training within the "Goldstein-Wong dialectic" is therefore to impart to an officer those skills that would make him or her a community resource in preventing crime and dealing with emergency/crisis situations, while recognising that he or she is just the first among equals in that community but at the same time can provide leadership in dealing with community problems; hence training for "partnership policing". 


\section{Research Methodology}

A descriptive survey design was adopted during the field study. The target population comprised regional security administrators in the North Rift and Eastern regions, trainers in the police training colleges and county police commanders. The study also targeted regional and community leaders such as peace monitors, regional commissioners, county commissioners and district commissioners.

The study purposively sampled 100 regional and community leaders from the Nyanza, Eastern and Rift Valley regions who responded to the questionnaires. Another 100 respondents from the National Police Service, including 60 police college instructors and 40 police commanders, were purposively sampled to respond to the questionnaires. These were officers who attended the various sensitisation forums on small-arms awareness that had been organised in their regions at that time. Gender considerations were paramount. The colleges that were visited were Wayando Police Academy, Ogongo Training School, Odera-Chune Police Training College and Farasi Training Depot. Focused group discussions (FGDs) were used to get responses from 15 PPOs in Terare and another 13 in Swanga. It was not possible to reach a large sample of PPOs with questionnaires and FGDs, due to their low level of education and nomadic pastoralist lifestyle.

The data collected during TNA was analysed both qualitatively (by developing themes and categories) and quantitatively through frequency counts and percentages. The data has been presented in the form of narratives and tables.

\section{Findings and Discussion}

\subsection{Needs of security stakeholders in relation to training of PPOs}

A total of 187 respondents gave their opinions as stakeholders, thereby generating a total of 132 responses in various categories. They highlighted the following thematic areas as vital for PPO training.

Figure 1: Needs of security stakeholders in relation to training of PPOs

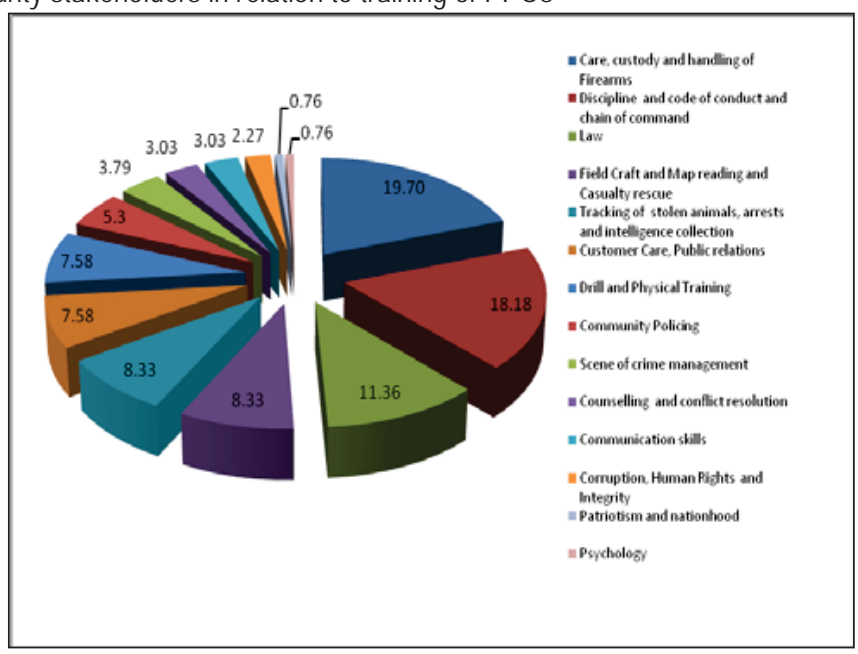

Figure 1 indicates that out of the 14 areas, the seven preferred by the majority for PPO training are care, custody and handling of firearms (19.70\%); discipline and code of conduct and chain of command (18.8\%); law (11.36\%); fieldcraft, map reading and casualty rescue (8.33\%); tracking of stolen animals, arrests and intelligence collection (8.33\%); customer care and public relations (7.58\%); and drill and physical training (7.58\%).

\subsection{Performance-related needs of PPOs}

A total of 187 respondents identified from a list of choices the specific police duties that they considered important or not 
important for the PPOs to be trained in. Figure 2 indicates by priority the areas they found important.

Figure 2: Important performance-related needs of PPOs

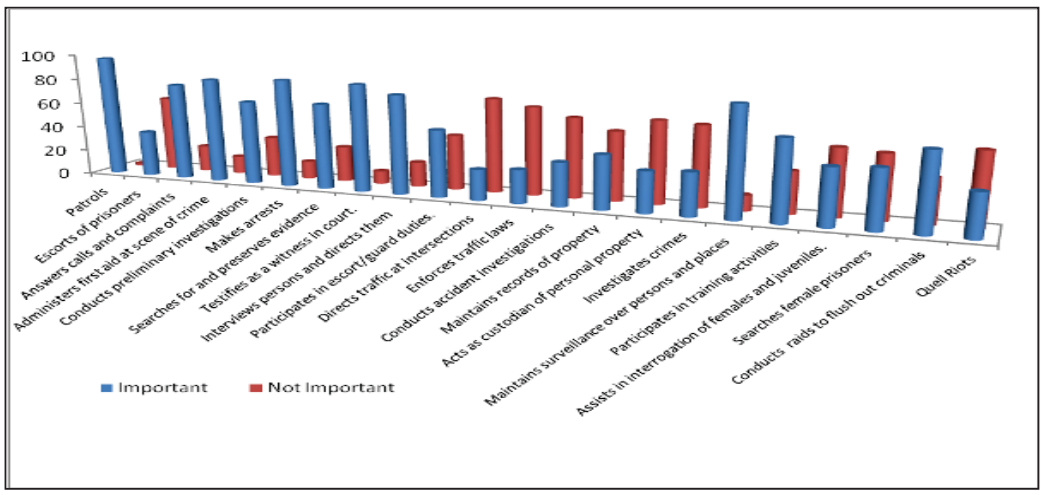

Figure 2 indicates that the majority of the stakeholders felt that such traditional tasks as patrols (96.79\%); arrests (86.10\%); surveillance (86.10\%); testifying in court (85.56\%); and administering first aid (83.42\%) are very important for the PPOs to perform. However, traffic duties (24.60\%), quelling riots (26.74\%) and investigation of crimes (34.22\%) were considered least important, perhaps due to the perceived low level of education of pastoralists and the absence of civil disturbance and traffic challenges in those areas.

Figure 3 indicates the knowledge, skills and abilities that the respondents felt were important for the PPOs to possess in order to perform their tasks.

Figure 3: Important knowledge, skills and abilities

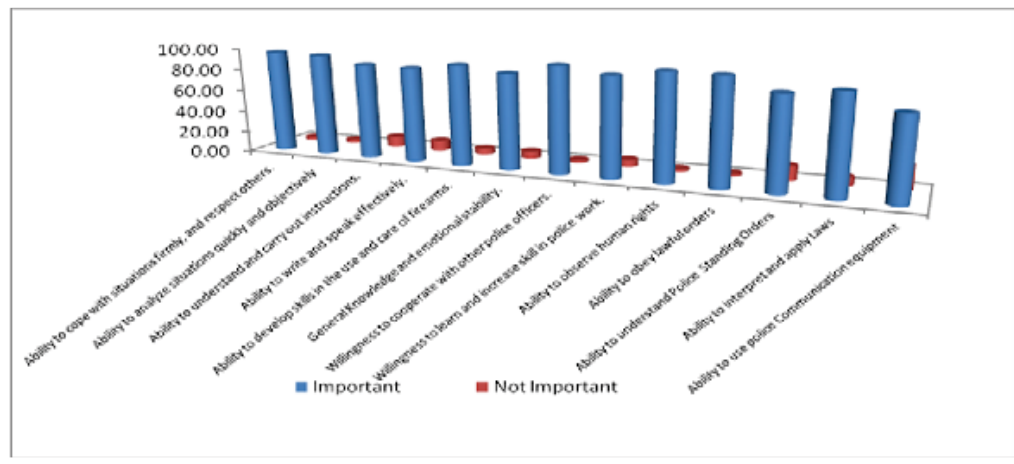

Figure 3 indicates that all the necessary knowledge, skills and abilities listed received favourable ratings, making them vital componets of PPO training programmes. Knowledge of human rights (97.86\%) topped the list of priorities, but it received a low ranking in Figure 1 . The explanation for this finding is discussed elsewhere in this paper.

\subsection{Individual training needs of the national police reservists}

Focused group discussions held with 13 PPOs at Swanga Conservancy and 15 PPOs in Wakondo town, Terare County, yielded the following thematic areas of training:

- handling of various firearms and range practices

- fieldcraft

- regular training

- legislation governing firearms and arrest 
- first aid

- presentation of evidence in court

- control of traffic within the conservancy

One PPO noted:

Some of us were just given firearms with no basic training at all on how to use it. We would very much appreciate if we are taught how to operate the firearm and also how to give first [aid] to our colleagues who may be injured during operations. ... Sometimes when we go to court to give evidence, we are usually challenged by the suspects to justify why we arrested them yet we are not police officers ... We usually do not know what to say because we don't know the law

The PPOs also highlighted that qualifications for training should be based on communication skills, discipline, physical fitness and interest. They also suggested an age bracket of between 18-40 years and a training duration of between three and six months. Another PPO noted:

It is important for a PPO to know how to read and write in Kiswahili so that one can be able to record the registration number of a vehicle inside the conservancy. Majority of the NPRs who do not know how to read and write have made efforts to be literate ... However those who are illiterate, especially the traditional PPOs, should not be neglected since the conservancies still rely on their experience during security operations ...

The biographical data indicated that the majority of the PPOs (76\%) are semiliterate (can read and write in a local language only) while a few (24\%) are illiterate.

\subsection{Discussion}

Figure1 shows that traditional subjects such as handling firearms; discipline; law; fieldcraft; map reading and casualty rescue; tracking stolen animals; arrests and intelligence collection; customer care and public relations; and drill and physical training received favourable ratings from the stakeholders as key training needs for PPOs. Similar results are seen in Figure 2, where the majority preferred such tasks as patrols, arrests, surveillance, testifying in courts and administering first aid. The individual PPOs also expressed the need to be trained in the same areas in addition to regular training, range practices and traffic control. However, these needs focus on producing the traditional police officer whose skills are at odds with the contemporary demands of community policing (Bradford \& Pynes 1999; Marion 1998; Kochur 1997; McLaughlin \& Donahue 1995; Ness 1991; Meadows 1986). In contrast, few stakeholders in Figure 1 have high regard for such subjects as community policing (5.30\%); scene-of-crime management (3.79\%); counselling and conflict resolution (3.03\%); communication skills (3.03\%); corruption, human rights and integrity (2.27\%); patriotism and nationhood $(0.76 \%)$; and psychology $(0.76 \%)$. Yet these subjects are considered crucial in training that is oriented towards community policing.

These findings can be attributed to the fact that the majority of the stakeholders were security officers and administrators whose orientation to security management had been based on traditional police training. To them, the measure of quality police training is not its relevance to community needs but its similarity to the training they underwent. Hence they believed that new concepts that have never been part of the traditional police training could not be recommended for PPOs. Nevertheless, researchers have faulted the "similarity syndrome" in police training for being less pragmatic in tuning the officer to his or her daily workload and policing challenges (Bradford \& Pynes 1999; Alpert \& Dunham 1997; Bayley \& Bittner 1984). In agreement, Goldstein (1987) criticises the tendency of police to be preoccupied with procedures at the expense of solutions and proposes a redefinition of the role of the police from that of law enforcers and crime fighters to that of problem-solvers. Hence, any intervention to professionalise PPOs that only emphasises the traditional concept of policing at the expense of the modern one would be counterproductive.

The finding that that majority of the PPOs (76\%) can only read and write in the local language or Kiswahili is likely to hinder efforts to impart cognitive, interpersonal and leadership skills (Metchik \& Winton1995). Even though Bullock (1995) and Carnevale and Carnevale (1993) contend that the contemporary police officer must be well educated so as to be a resource and a problem-solver, this level of competence could be difficult to achieve in the PPOs.

In Figure 3, knowledge of human rights (97.86\%) tops the list of priorities, yet it receives a low ranking in Figure 1 from the same respondents. The implication is that as recipients of police services, communities will continue to demand from police officers more competencies than they are willing to train them in as policing authorities. Marion (1998) also established that such human rights-related areas as ethics, information on the elderly population and victims of crime have been neglected in police training.

Figure 3 also indicates that the following traits of a community-oriented police officer were largely preferred by the stakeholders: willingness to cooperate (97.86\%); ability to cope with situations firmly and respect others (95.72\%); ability 
to analyse situations quickly and objectively (94.65\%); ability to write and speak effectively (87.70\%); willingness to learn and increase skills in police work (91.98\%); and general knowledge and emotional stability (88.24\%). These traits illustrate the quality of police officer that communities expect. As Goldstein (1990) emphasises, these qualities will not only ensure a secure and crime-free atmosphere but also enhance trust and improve police-public partnerships. Within Wong's Social Resource theory, these traits would enable officers to be dynamic enough to offer client-based police services, while fulfilling their roles as community policing resources (Wong 2009).

\section{Conclusion}

The foregoing discussion reflects that, whereas the organisational, task-oriented and personal training needs of PPOs point towards a traditional curriculum, stakeholders' expectations of the curriculum and training are to produce a police officer equipped with the requisite skills for delivering community policing. The dilemma of professionalising PPOs in Kenya therefore lies not so much in delivering the much-desired traditional curriculum but in reorienting the curriculum towards the much-desired resource- (Wong 2009) and problem-based (Goldstein 1987) proactive policing, within a semiliterate population. A hybrid broad-based curriculum model, which combines both the modern (Goldstein 1987) and postmodern (Wong 2009) aspects into "partnership policing", but delivered at a very basic level, would be a significant breakthrough. In this regard, recruitment of trainers should aim at tapping the most educated among the semiliterate population with the hope that the language of instruction and the content of the curriculum should pose little difficulty to the trainees. More research is still required on the training methodology appropriate for delivery of this curriculum.

\section{References}

Anderson, JE. 2000. Training needs assessment, evaluation, success, and organizational strategy and effectiveness: An exploration of the relationships. Doctoral dissertation. Utah State University. Logan, UT.

Alpert, GP \& Dunham, RG. 1997. Policing in urban America. 3rd edition. Prospect Heights, IL: Waveland.

Bayley, DH \& Bittner, E. 1984. Learning the skills of policing. Law and Contemporary Problems 47(4):35-59.

Bevan, J. 2008. Blowback: Kenya's illicit ammunition problem in Turkana North District: Small Arms Survey. Geneva: Graduate Institute of International and Development Studies.

Boydell, T. 1976. A guide to the identification of training needs. London: British Association for Commercial and Industrial Training.

Bradford, D \& Pynes, JE. 1999. Police academy training: why hasn't it kept up with practice? Police Quarterly 2(3):283-201.

Brand, RF \& Peak, K. 1995. Assessing police training curricula: consumer reports. Justice Professional 9(1):45-58.

Brown, J. 2002. Training needs assessment: a must for developing an effective training program. Public Personnel Management 31(4):569-578.

Bullock, T. 1995. Personality profiling. PIFIA Protector Journal of the Police and Fire Fighters' Association 8(3):12; 37.

Carnevale, AP \& Carnevale, DG. 1993. Public administration and the evolving world of work. Public Productivity and Management Review 17:1-14.

Cheng, H \& Hung, S. 2012. The Utility of O-T-P Model in Taiwan Coast Guard. Public Personnel Management 41(1). Spring. Available at: ppm.sagepub.com (accessed on 24/07/ 2013).

Cleveland, G. 2006. Using problem-based learning in police training. The Police Chief 3(11).

Daffron, S, Goulet, G, Gray, J \& Viada, J. 2008. Developing curriculum for police officers and firefighters: tips to follow and pitfalls to avoid, in Curriculum Development for Adult Learners in the Global Community Volume I: Strategic Approaches, edited by VCX Wang. Malabar, FL: Krieger:171-206.

Dwyer, G \& Dwyer, D. 2004. The need for change: a call for action in community police training. Federal Bureau of Investigations Law Enforcement Bulletin 73(11):8-24.

Flosi, E. 2011. Curriculum development for law enforcement: Pedagogy versus Andragogy. Policeone.com. Available at: http://www.policeone.com/Officer-Safety/articles/3773478-Curriculum-development-for-law-enforcement-Pedagogy-versusAndragogyl

Goldstein, IL \& Gessner, MJ. 1988. Training and development in work organizations, in International Review of Industrial and Organizational Psychology, edited by CL Cooper \& I Robertson. 3rd edition. New York: Wiley.

Goldstein, IL. 1991. Training in work organizations, in Handbook of Industrial and Organizational Psychology, edited by MD Dunnette \& LM Hough. 2nd edition. Palo Alto, CA: Consulting Psychologists Press.

Goldstein, H. 1987. Improving policing: a problem-oriented approach. Crime and Delinquency 25(2):236-258.

Goldstein, H. 1990. Problem-Oriented Policing. New York: McGraw-Hill.

Ghufli, A. 2012. Training needs analysis: an empirical study of the Abu Dhabi Police. Brunel Business School Doctoral Symposium 2728th March 2012. Brunel University, London.

Holton, E, Bates, R \& Naquin, S. 2000. Large-scale performance-driven training needs assessment: a case study. Public Personnel Management 29(2):249-268. 
Kelling, GL, Wasserman, R \& Williams, H. 1988. Police accountability and community policing, in Perspectives on policing, .Washington, DC: National Institute of Justice.

Kennedy, R. 2003. Applying principles of adult learning: the key to more effective training programs. Federal Bureau of Investigations Law Enforcement Bulletin 72(4):1-5.

Kochur, CJ. 1997. Screening for success in community policing. Community Policing Exchange 25(2). March-April.

Leat, MJ \& Lovell, MJ. 1997. Training needs analysis: weaknesses in the conventional approach. Journal of European Industrial Training 21(4):143 -53.

Lentz, SA \& Chaires, RH. 2007. The invention of Peel's principles: a study of policing 'textbook' history. Journal of Criminal Justice 35 (1):69-79.

Mager, RF \& Pipe, P. 1984. Analyzing Performance Problems. 2nd edition. Belmont, CA: Lake Publishing.

Marion, N. 1998. Police academy training: are we teaching recruits what they need to know? Policing: An International Journal of Police Strategies \& Management (211):54-79.

Metchik, E \& Winton, A. 1995. Community policing and its implications for alternative models of police officer selection, in Issues in community policing, edited by PC Kratcoski \& D Dukes. Cincinnati, OH: Anderson:107-123.

McGehee, W \& Thayer, PW. 1961. Training in Business and Industry. New York, NY: John Wiley \& Sons.

McLaughlin, V \& Donahue, ME. 1995. Training for community-oriented policing, in Issues in community policing, edited by PC Kratcoski \& D Dukes. Cincinnati, $\mathrm{OH}$ : Anderson.

Meadows, RJ. 1986. Beliefs of law enforcement administrators and criminal justice educators toward the needed skill competencies in entry-level police training curriculum. Journal of Police Science and Administration 15:1-9.

Mkuutu, K. \& Wandera, G. 2013. Policing the periphery: opportunities and challenges for Kenya Police Reserves. Small Arms Survey, Graduate Institute of International and Development Studies Geneva, Switzerland.

Mkuutu, K. 2005. Pastoralist conflict, small arms and governance in the North Rift, Northeast Africa. Doctoral thesis, University of Bradford.

Ness, JJ. 1991. The relevance of basic law enforcement training - does the curriculum prepare recruits for police work: a survey study. Journal of Criminal Justice 19(2):181-193.

Oliver, WM. 1998. Community-oriented policing: a systematic approach to policing. Englewood Cliffs, NJ: Prentice Hall.

Safer World and Amani Forum 2006. Developing a strategy to respond to the Government of Kenya's Disarmament Programme. Report of a round-table meeting organised by Safer World and the Great Lakes Parliamentary Forum on Peace - Amani Forum.

Scott, D \& Deadrick, A. 1982. The nominal group technique: application for training needs assessment. Training and Development Journal 36(6):26-33.

Taylor, PJ, O'Driscoll, MP \& Binning, JF. 1998. A new integrated framework for training needs analysis. Human Resource Management Journal 8(2):29-50.

Van Eerde, W, Tang, K. \& Talbot, G. 2008. The mediating role of training utility in the relationship between training needs assessment and organizational effectiveness. The International Journal of Human Resource Management 19(1):63-73.

Wepundi, M, Nthiga, E, Kabuu, E, Murray, R \& Del Farte, AA. 2012. Availability of small arms and perceptions of security in Kenya: an assessment. Small Arms Survey, Geneva: Graduate Institute of International and Development Studies. Available at: http://www.smallarmssurvey.org/fileadmin/docs/C-Special-reports/SAS-SR16-Kenya.pdf Wepundi, M. 2011. An analysis of disarmament experiences in Kenya. Regional Centre for Small Arms. Nairobi: RECSA.

Wong, KC. 2009. Chinese Theory of Community Policing. Chinese Policing: History and Reform. New York: Peter Lang. 
